\title{
How to Develop Writing Skill through Constructivist Design Model
}

\author{
Dr. Abeer AL-Ghazo \& Dr. Samer M. Al-Zoubi
}

Ajloun National University

Jordan

\begin{abstract}
The main aim of this quasi- experimental study was to determine the effect of constructivist learning design on college students' writing skill. The participants of this study consisted of two sections 15 students in each selected randomly from the English Language and Literature Department at Ajloun National University. In order to achieve the study objectives, all participants in both control and experimental groups took a pre-test, and a post- test in writing skill to determine if there was any significant difference in writing performances over a semester. The writing pre-test essays were submitted prior to the treatment and were compared to the writing post-test essays that were submitted after the treatment (about five weeks later). The writing post-test essays were scored and analyzed. The results revealed that there was not any significant difference between mean scores of the EFL students in the control and experimental groups on the pre-test. Moreover, the results also showed that there were clear differences between the mean scores of the EFL students in experimental group in the post-test in favour of the experimental group .
\end{abstract}

Keywords: EFL students, constructivist design, writing skill

\section{Introduction}

"It seems possible for a person who accepts constructivism as a philosophy to adopt a variety of educational practices or for a teacher who uses constructivist classroom practices to justify doing so in a variety of ways, some of which might not philosophically be constructivist at all." (Phillips ,2000 p. 18)

Writing is an essential language skill that EFL learners need to achieve while they were learning English as a foreign language. It is one of crucial communicative skill because that helps learners to develop their mental thinking. Vygotsky (1978) explained that constructivists place the learner at the center of the equation; the idea is that the learner constructs knowledge rather than passively absorbing it. Meaning is constructed by each learner via their experiences and in their own ways and means. It is based on according to how the learner's understanding is currently organized. An individual's knowledge is a function of one's prior experiences, mental structures, and beliefs that are used to interpret objects and events. Torwong (2003) indicated that writing is a basic skill for communicating with other people from all over the world. Brown (1987) believed that the communicative approach considers writing as a conscious basic skill that requires mental effort in order to produce meaningful and communicative ideas. Bello (1997) showed that writing is a productive language skill. However, writing skill plays an important role in improving language acquisition as learners experiment with words and sentences to communicate their ideas efficiently and effectively in addition to reinforce their vocabulary and grammar which they learn in their classrooms.

Conley (1995) stated that writing skill makes one's experiences and thoughts and it helps in learning many things effectively and efficiently. French and Roder (1992) indicated that writing skill is considered as the main skill in the EFL curriculum that it is associated with EFL learner's communicative skills and their creativity. They also stated that learners could develop and improve essay writing through their schooling. EFL learners have to improve and develop some writing skills such as; writing meaningful sentences, coherent, and well-organized ideas, using communicative language, choosing suitable words and idioms and using an appropriate writing mechanics. Learners in general are very weak in the writing skill, and they need to improve and enhance their writing performance. They face many difficulties and obstacles in composing which it is required to produce good sentences and ideas, arranged them logically, and using suitable words, vocabulary items and structures. It must confess that Jordanian EFL students suffer from weaknesses in writing skill in spite of the efforts of the many curricula designer and educationalists to overcome this weakness (Toubat, 2003). 
In fact, EFL learners are weak in this crucial skill, and they have to enhance their writing performance in order to produce meaningful sentences that comprise coherent text. Many Jordanian researchers found that most Jordanian students are unable to write correctly (Ababneh, 1996; Abed, 1990; Al-Hasan, 2006; Batayneh, 1986). Alkhresheh (2010) states, "in spite of the long period where English was taught in Jordanian schools and the importance given to its curriculum, it is generally observed that students are unable to write a simple meaningful sentence without committing an error" (p. 105). Al-Abed Al-Haq and Al-Sobh (2012) believe that the techniques and strategies of teaching writing are one of the most reasons for students' weakness.

Most of the traditional strategies have not improved the learners' abilities in writing skill. Thus, EFL students need more practice to gain English writing skills and there should be special attention to students of English who have limitations in their English learning abilities. Consequently, teachers have to choose suitable and effective activities and strategies for developing their students 'writing skills. As an effective skill, writing is still considered a problem for EFL students; a need is felt to find out some strategies of learning and teaching that can help them to improve their writing performance. Still, constructivism has an important implication for learning and teaching situation. Hoover (1996) indicated that teaching cannot be viewed as the transmission of information and knowledge and those constructivist teachers do not take the role of the "sage on the stage", they play a role as "guides on the side," who provide their learners with opportunities to learn effectively and efficiently.

Clements, (1997) also stated that teachers should arrange the learning situation for students to explain the topic, provide learning environment that exploit inconsistencies between learners' new experiences and their current understandings .Though, Constructivist Learning Design is one of the techniques that can make classroom writing more interactive. The main goal of this design is to direct teachers to new ways of thinking and break from the traditional way of reasoning. CLD contributes to the learners to find creative solutions to problems they face. It is used to encourage those learners to generate ideas effectively and efficiently. It can be considered, in the writing process, as a means to enhance students' motivation to write in an effective and correct way.

In order to instruct learners effectively to employ CLD, George W. Gagnon, Jr. and Michelle Collay (2006) stated that "Constructive Learning Design emphasizes six important elements. These elements are Situation, Groupings, Bridge, Questions, Exhibit, and Reflections".

Situation: develop goals, tasks, and curriculum standards

Grouping: group students and materials, and cooperative learning

Bridge: recall prior knowledge using students' cognitive maps, skills, values, motivation, and expectations

Task: use higher level thinking skills and problem-based learning

Exhibit: arrange student portfolios and work samples

Reflection: synthesize critical thinking and knowledge"

Therefore, engaging students in tasks, help them think for themselves, and support them in making meaning of their learning!

\subsection{Statement of the Problem}

Many researchers indicated that Jordanian students are unable to write a short paragraph even a simple meaningful sentence without committing an error. Al-Abed Al-Haq and Al-Sobh (2012) stated that there are many reasons behind EFL learners' weakness in the writing skill, the most essential reason is the strategies and techniques of teaching. Moreover, they believe that there is a need to adopt new teaching techniques for teaching writing skill that may help students be better writers. Toubat, 2003; Batayneh, 1986; AL-Quran, 2002 also believe that teachers in classroom concentrate on grammar and structure rather than the writing process and their current strategies and techniques they used are not effective. The researchers believed that the effective teaching strategies may positively affect students' writing skill. Al-Bataineh (2010) assumed that the weakness of writing skill may be due to the failure of using the traditional techniques and methods of teaching in helping both students and the teachers to learn and teach this skill efficiently. The researchers thought that there are many reasons stand behind students' weakness such as ineffective English teaching methods, i.e. students learn English in a very traditional lecture teaching style and their low English proficiency level. It is more important to vary in the methods and strategies teachers should use to develop writing skill in the English classroom. 


\subsection{Purpose and Question of the Study}

In the light of what has been mentioned above, the researchers of this study tried to shed the light on the importance of the constructivist learning design to develop students' writing skill. In specific, this study aimed at answering the following main question:

1. Does constructivist learning design have any significant effect on developing and promoting EFL learners' writing performance?

\subsection{Significance of the Study}

Since this study tried to investigate the effect of constructivist learning design on EFL students' writing skill, it is hoped that the findings of this study may provide a better understanding of how teachers' practices are influential to develop their students' writing skill. This study can also be significant for both practice and research into the field of teachers training.

It may contribute to more efficient learning designs that may have a positive implications on the quality of the teaching profession. Most of the traditional techniques and strategies have not improved the students' abilities in writing. Therefore, the researcher adopts a technique based on constructivist design that may enhance students' performance in writing.

\subsection{Limitations of the Study}

The findings of this study were limited according to the following reasons:

1. This study was applied at EFL learners at ANU in the second semester in the scholastic year 2016-2017.

2. The study is limited in number. Only 15 Jordanian EFL students participated in the study. The sample was chosen randomly to achieve the purpose of the study.

3. Evaluating and assessment students` writing skill was restricted to the specific strategy chosen by the researcher.

\section{Literature review}

There were many studies that showed that constructivist teaching can be very effective across subjects and academic ability. For example, Boekaerts and Minnaert (2006) examined how levels of interest in the content material that related to these three psychological need states: perceived autonomy, competence and social relatedness. The participants were 95 university sophomores in the Netherlands. The results revealed that constructivist strategies and techniques do not satisfy all these three psychological needs simultaneously. If a majority of psychological needs is satisfied, learners feel they had a positive learning experience. Linh, $\mathrm{N}$ and Suppasetseree,S (2015) conducted a study to develop an instructional design model for assisting students in learning collaboratively using Face book groups to enhance their English writing skills at the beginning stage of their university education. In their study, collaborative learning and writing, the theory of instructional design, and five previous instructional design models were analyzed, and synthesized. Moreover, they adapted seven steps model for designing an instructional model from Brahmawong and Vate-U-Lan (2009) to develop the instructional design model. The results showed that the elements of the FBCL Model was satisfactory and appropriate for giving EFL writing instruction in Face book groups. The FBCL Model may also be beneficial in providing an instructional framework to EFL writing instructors and instructional designers.

Supriyadi ( 2013)conducted a study to develop teaching material that depends on constructivism approach in order to improve learners' skill in writing scientific paper. His study also tried to test the effectiveness of product in learning how to write scientific paper in classroom. He used R2D2 development model in this study to achieve the main objectives of the study. While qualitative data was analyzed by domain technique, quantitative data was analyzed by SPSS 16.0 for windows. The results showed that using the constructivism approach in learning reflected with four activities. These activities are orientation, exploration of concept, interpretation/concept inquiry, and concept application. The results also revealed that learning outcomes in writing scientific paper was improved through learning process with teaching material of development product . Moallem, M (2001) used an instructional design principles and models to design and develop Web-based course. In his paper, he tried to prove that there is a useful link between learning theories and instructional design practices. When the learners implement the instructional design in creating WBI, they can construct their learning experiences in alignment with prescribed curriculum. 
The results showed that learners' performance in this Web-based course indicated that the objectives of this course were achieved. In addition, students agreed that the course helped them to work independently and collaboratively.

ArdaArikan (2006) reported on an experimental syllabus design used in a writing skills course used at English Language Teaching department in a Turkish University. In this syllabus, and by using the insight derived from constructivist theory, topics and subjects that related to English language teaching are merged with knowledge derived from reading traditional academic writing and reflective writing through many activities such as discussion, peer reviewing, and journal keeping. He designed a rubric to measure students' writing. The results showed that when students were asked to write academically by using their practical knowledge in a reflective manner, they were having a high motivation by the writing task. All these studies were conducted to explore how the constructivist theory may benefit EFL learners in classroom.In light of what has been mentioned above, the researcher of this study tried to shed the light on the importance of the constructivist learning design to develop our students' writing skill.

\section{Methodology}

\subsection{Research Design}

This research was considered as an experimental design as the main aims to examine the influence of constructivist learning design and developing learners' writing competence. The participants of this study were randomly selected and were divided into groups; the experimental and control groups. The learners in the experimental adapted the constructivist learning design, while the participants in the control group did not receive any strategy-based instruction. Both groups received two tests (pre and post test ), one before implementing the study and another one after the instruction process, to check the effect of the instruction procession the participants' writing competence. These steps constituted the principles of quasi-experimental design. The main variables in this study divided into an independent variable, which is the constructivist learning design, and the dependent variable was the writing performance and comprehension of control and experimental groups.

\subsection{Participants of the Study}

The participants of the study consisted of two sections of Writing (1) Course; level one with 15 students in each one selected randomly from the English Language and Literature Department at Ajloun National University. One section was assigned as a control group; whereas the second section was assigned to represent the experimental one. The control group were taught to write an essay in the traditional way while the experimental group were taught the same topic by using the constructivist learning design.

\subsection{Research Instrument}

To apply and achieve the objectives of the study, the researchers prepared a writing test in advance. The subjects from both the experimental and control groups were required to take two tests, one pre- writing test, and one postwriting test to determine whether there were significant differences in their writing performances over a semester.

\subsubsection{Validity and Reliability of the Instruments}

To measure the validity of the writing test, a number of TEFL and linguistics specialists in Jordanian universities are going to assess the test.To check the reliability of the test, the researchers conducted a pilot study and modified the writing test accordingly. Then, the researcher used Cronbach's alpha to gain a satisfactory reliability. The value of Cronbach's alpha for pre-test was 0.82 that indicated good and satisfactory reliability value.

\subsection{Procedures of the study}

A pre-test was prepared in advance and it was applied before the experiment and at the very beginning of the semester to confirm and make sure that the writing abilities of all the participants in the two classes were really at the same level. This test was an in-class writing test in which students were given 45 minutes to plan, write and revise a piece of writing. After their writings were handed in, they were checked by two teachers who have been teaching English for more than eight years and have been trained on the standards for evaluating writing (adapted from Phillips,2003 ) of the writing scores. The full scores of the writing was out of 20. The two teachers calculated each of the writing and the mean scores of the two teachers calculated the scores of each of the writing. The score of the Test of Written English (TWE) was a separate one on a scale of the six criteria, where one is the worst score and six is the best score. The examinees must write an essay on a given topic in 45 minutes. These criteria are: 
1-The writer is not capable of conveying ideas in written English.

2- The writer shows a minimal ability to convey ideas in written English.

3- The writer shows evidence of organizational, structural and grammatical skills that still need to be improved.

4-The writer has adequate organizational, structural and grammatical skills. The essay contains a number of errors.

5- The writer has good organizational, structural and grammatical skills. The essay contains some errors.

6- The writer has very strong organizational, structural and grammatical skills." (Zawahreh, 2011).

\subsubsection{The Implementation of the Constructivist Learning Design}

These elements provided teachers with a clear picture of the process of students learning.

1- Situation: Teachers are asked to develop and arrange the situation for learners to explain the main topics they are going to write about. Teachers have to explain for their students that they are going to deal with different writing activities such as describing the process of solving problems, answering some questions, making their decisions, making conclusions, or setting aims and goals. In other words, students have to deal with different topics of writing. In this phase, there should be emphasis on what you as a teacher expects from your students to do and how they will make their own meaning. Teachers design the situation based on their assessment of students' learning approaches, interests, and needs as this is the best method to start training students on how to start writing when they are engaged in things they are fond of.

2- Groupings: Teachers have to select a process for groupings of both materials and students. They have to know how they are going to divide the students into groups. They may divide them into big groups or small ones. Teachers may divide them according to their counting off, choosing a color or piece of fruit, or similar clothing. Moreover, teachers are asked to rearrange the material that students are going to use by presenting different techniques such as physical modeling, graphically representing, numerically describing, or students may be asked to write freely about their collective experience. Teachers may follow a certain design in grouping the students according to their abilities as well as the availability of the needed material.

3- Bridge: It is an introductory activity that is designed to examine the students' prior knowledge. This stage looks like building a bridge between what the students know and they want to know. This can be achieved by explaining the situation for the students. To explain the situation, teachers may present a simple problem to solve, class discussion, playing a game, or making lists. This action can be done for the students before they are put in groups or after they are grouped. Teachers may prepare a simple assessment of what students already know as a bridge to what they seek to learn.

4- Questions: Questions could be raised during each element of this Learning Design. Teachers may get the questions from students and then they form new other questions to encourage them to present and explain their thinking. Teachers may choose and decide the guiding questionsthat could be used to do many useful things such as introducing the situation, arranging the groupings, setting up the bridge, keeping active learning going, prompting exhibits, and encouraging reflections. Teachers may prepare the questions to assess students' understanding of the concepts, skills, or attitudes they are trying to learn from the presented material.

5- Exhibit: Teachers are advised to encourage students to exhibit a record of their thinking by sharing it with their colleagues in the classroom. This could be achieved by following different ways such as writing a description on cards and then giving a verbal presentation for what they describe, making a chart, visual representation, role playing, constructing a physical representation with models, and making a video tape, photographs, or audio tape for display. Teachers are going to arrange an exhibit for their students to record and present what they thought and submit it to others for assessment.

6- Reflections: Teachers ask students to reflect their learning by explaining the situation they have learned, and then they are given the opportunities to see the exhibits from others. By adopting this strategy, students are expected to remember from their previous experience about different things such as; feelings in their spirit, images in their imagination, and languages in their internal dialogue, their attitudes, skills, and concepts will be taken out the door. After that, teachers are asked to arrange, reflect, and present what students' have learned. Moreover, students have to express the internal process of representations as a context for self-assessment of individual learning. 


\section{The results and their discussion}

In order to investigate the importance of the constructivist learning design to develop students' writing skill, the findings provided ,in this section, to answer the research question; Does constructivist learning design have any significant effect on promoting language learners' writing performance? The researchers used the independent samples T-Test to analyze the possible variances in EFL students' writing performance between the control and experimental groups participated in an essay-writing test. Then, and in order to check the homogeneity of the two groups in the writing performance level, the students' scores in the pre-test were analyzed.

Table 1. presents the means and standard deviations which obtained by the both groups, experimental and the control group on the pre-test and the post-test.

Table (1) Means and standard Deviations for participants' scores on the pre and post writing tests

\begin{tabular}{|c|c|c|c|c|c|c|c|c|c|c|c|}
\hline & & \multicolumn{5}{|c|}{ Control Group } & \multicolumn{5}{|c|}{ Experimental Group } \\
\hline ธี & & Number & M & ST.D & $\mathbf{T}$ & sig & $\mathbf{N}$ & M & ST.D & $\mathbf{T}$ & sig \\
\hline d & $\begin{array}{l}\text { Pre- } \\
\text { test }\end{array}$ & 15 & 19.48 & 3.61 & .29 & .21 & 15 & 21.19 & 3.89 & & \\
\hline 占 & $\begin{array}{l}\text { Post- } \\
\text { test }\end{array}$ & 15 & 12.9333 & 2.01660 & & & 15 & 24.6000 & 3.31231 & 8.3 & .001 \\
\hline
\end{tabular}

According to the analysis of the pre-test scores, Table (1) showed that there were not any significant differences $(t=-0 . .29 ; \mathrm{p}>.05)$ between the mean scores of the students in the two groups. This indicated that the experimental and control groups were homogeneous in terms of writing performance level before the beginning of the treatment and experiment. In order to see if the learners in the experimental group had performed effectively and differently, their scores on the post- test compared with their scores on pre- test using a paired t-test. Given the information in the table above, and after the experiment, it is obvious that the mean score obtained by students in the experimental group was (24.60) which was higher than the mean score obtained by those in the control group that was (12.9). This means that there were clearly differences between the mean scores of the EFL students in both groups; control and experimental in the post-test in favor of the experimental group.

\section{Conclusion}

The ultimate goal of the study was to figure out the impact of constructivist learning design on developing students' writing skill at Ajloun National Universiy. It was obvious that student's writing performance by the help of suggested design, which was constructivist learning design, was better than the traditional teaching to control group who did not receive any instructions. The findings showed that constructivist learning design had a significant role in promoting the students' writing skill. This means that the mean scores of student's writing performance revealed significant difference between control and experimental groups in favour of the experimental group. The students' performance in an essay-writing test was high due to the experiment's treatment. Results of the analysis shown in Table 1 revealed that the answer of the question is positive. Constructivist learning design could influence students' writing skill performance .More recently, this design is regarded as a crucial one in improving writing skill as revealed in the this research, it is still worth to put much emphasize on constructivist learning. This supports previous research claiming students to improve their writing abilities when they use constructivist learning. (Boekaerts and Minnaert 2006; George W. Gagnon, Jr. and Michelle Collay 2006).

In general, the results of this study indicated that EFL students' writing skills and abilities could be improved by employing constructivist learning design. Teaching under this design showed that there will be progress in their essay writing in terms of the organization of content ,mechanics of writing, and language that emerged from their creative thinking abilities. This study has some implications for language learning and teaching. Hence ,EFL learners will become better ones if they become more aware of their learning processes. Teachers may increase their students' confidence in writing, reinforce their creativity and self-awareness by familiarizing them with constructivist learning strategies and designs. 


\section{References}

Ababneh, S. (1996).Problems facing EFL Jordanian students in expository writing in Arabic and English (Unpublished master's thesis).Yarmouk University, Irbid, Jordan.

Abed, R. F. (1990). The effect of feedback on the writing performance of community college English language majors (Unpublished doctoral dissertation).The University of Jordan, Amman, Jordan.

Al-Abed Al-Haq, F., \& Al-Sobh, M. (2012).Online linguistic messages of the Jordanian secondary students and their opinions toward a web-based writing instructional EFL program. International Journal of Humanities and Social Science, 2(6), 228-299.

Al-Hasan, S. M. (2006). The effect of a proposed conference based programme on developing writing and critical thinking skills of upper basic stage EFL students in Jordan (Unpublished dissertation). Amman Arab University for Graduate Studies, Amman, Jordan.

Al-khresheh, M. (2010).Interlingua interference in the English language word order structure of Jordanian EFL learners. European Journal of Social Sciences, 16(1), 103-113.

Al-Quran, M. (2002). The Class-Function Confusion in the Complex Sentence Structure: A Study of EFL Student Composition Errors, DIRASAT: Human and Social Science, 20 (3), 821-835.

ArdaArikan (2006).The Value of Reflection in Writing Courses in ELT Preservice Teacher Education Programs .The Asian EFL Journal. Teachers Articles November .Vol (16) 1-16.

Batayneh, R. (1986). A Contrastive Text Linguistic and Discourse Analysis, Insights into Teaching Writing at Advanced Level with Special References to the Jordan Context. Unpublished Master Thesis, Department of Modern Language, University of Salford

Bello, T. (1997).Writing Topics for Adult ESL Students. Paper presented at the 31st Annual Teachers of English to Speakers of Other Language Convention, Orlando, Fl, USA

Boekaerts, M., \&Minnaert, A. (2006).Affective and motivational outcomes of working in collaborative groups. Educational Psychology, 26:2, 187-208, DOI: 10.1080/01443410500344217

Brown, H. D. (1987). Principles of language learning and teaching. Englewood Cliffs, NJ: Prentice Hall.

Clements, D. H. (1997).(Mis?)Constructing constructivism. Teaching Children Mathematics 4(4) 198-200.

Conley, M. (1995).Content reading instruction: A communicative approach (2nd ed.). New York: McGraw-Hill, Inc.

French, N., \&Rhoder, C. (1992).Teaching Thinking Skills. Garland Publication, INC, NY, USA, 238

George W. Gagnon, Jr. and Michelle CollayG.(2006). "Constructivist Learning Design”. University of California, Berkeley, UK, Prairie Rainbow Company.

Hoover, W. A. (1996). The practice implications of constructivism. SED Letter 9, (3).

Linh,N and Suppasetseree, S. ( 2015 ). The Development of an Instructional Design Model on Face book Based Collaborative Learning to Enhance EFL Students' Writing Skills. IAFOR International Conference on Language Learning - Dubai .Official Conference Proceedings.

Moallem ,M (2001).Applying Constructivist and Objectivist Learning Theories in the Design of A Web-Based Course: Implications for Practice. Educational Technology \& Society .4 (3)

Phillips, D.C. (2000). Constructivism in Education. Chicago: University of Chicago Press, 6. Quoted in Richardson 2003, 1624-25.

Supriyadi ( 2013). Developing Teaching Material of Writing Scientific Paper using Constructivism Approach. Journal of Education and Practice.4(.24)34-41.

Torwong, P. (2003). Peer Response Technique: A Proposed Model for EFL Writing. (Unpublished Doctoral Thesis).Suranaree University of Technology, Thailand

Toubat, M. (2003).The Effect of a Discoursal Technique on the Writing Skills of the Jordanian Academic Eleventh Graders. Unpublished Ph. D. Dissertation, Amman Arab University, Amman, Jordan.

Vygotsky, L. S. (1978). Mind in society: The development of higher psychological processes. Cambridge, MA: Harvard University Press. 
Zawahreh, F.(2011). Perceived vs. actual linguistic and pedagogical competences of EFL Jordanian secondary stage teachers. Unpublished Doctoral Dissertation, Yarmouk University, Jordan.

\section{Appendix A}

\section{A. Write two supporting sentences for each the following topic sentences:} 1.My friend loves animals.

(2 points)

a.

b.

2. My high school years were the best time of my life.

(2 points)

a.

b.

3. My most valuable possession is a handmade carpet.

(2 points)

a.

b.

B. Write a topic sentence for this title 'A talented Brother'. (2 points)

c. Write a well-organized essay on ONE of the following topics:

(12 points)

1. Giving up Smoking

2. University Education

3. A successful Vacation at the Beach

4. My Favorite Sport is Soccer 